\title{
Ganyong-kelor snack bar's glycemic index as a diet for diabetics
}

\author{
Diyan Yunanto Setyaji ${ }^{*}$, Fransisca Shinta Maharini ${ }^{2}$
}

\begin{abstract}
Background: Lack of insulin or the inability of cells to respond to insulin causes high blood glucose levels or hyperglycemia, a hallmark of diabetes. Consumption of foods with a low glycemic index and high fiber has been shown to provide the same benefits as pharmacological therapy in the control of postprandial hyperglycemia and can prevent the incidence of hypoglycemia in people with diabetes. Ganyong (Canna edulis) is a food source of carbohydrates and fiber. Kelor (Moringa oliefera) contains protein and some phytochemical compounds which have a hypoglycemic effect.

Objectives: The objective of the study was to analyze the glycemic index of ganyong-kelor snack bars as a diet for diabetics.

Materials and Methods: Ten respondents fasted for 10 hours and checked their fasting blood glucose levels, then consumed 105 grams of bread as the reference food. Every 30 minutes after eating, the blood glucose levels were checked. In the following week, after fasted, all respondents consumed 157 grams of a ganyong-kelor snack bar and checked their blood glucose levels every 30 minutes.

Results: Every 100 grams of ganyong-kelor snack bar contains 230.13 kcal, 31.97 grams of carbohydrates, 9.25 grams of fat, and 4.75 grams of protein. In this study, bread was used as a reference food. If bread was corrected with glucose as a reference food, the glycemic index of the ganyong-kelor snack bar was 38.08. The calculation of the glycemic load used the converted-glycemic index and the total carbohydrates contained in 100 grams of the food. Ganyong-kelor snack bar had a glycemic load value of 12.10 .

Conclusions: Ganyong-kelor snack bar had good nutritional content and was categorized as food with a low glycemic index. The hypoglycemic effect of the ganyong-kelor snack bar came from its high fiber content. Ganyong-kelor snack bar can be consumed as a healthy snack for diabetic people.
\end{abstract}

Keywords: Ganyong; Canna; Kelor; Moringa; Diabetes

\section{BACKGROUND}

Diabetes mellitus is a chronic condition that occurs as a result of increased levels of glucose in the blood caused by the body's unable to produce sufficient amounts of insulin or the body is unable to use the insulin produced effectively. ${ }^{1}$ Lack of insulin or the inability of cells to respond to insulin causes high blood glucose levels, or hyperglycemia, which is a hallmark of diabetes. ${ }^{2}$ In 2017 the prevalence of diabetes mellitus globally is $8.8 \%$ or around 425 million adults with $85-95 \%$ of these cases are type 2 diabetes mellitus and is expected to increase to $9.9 \%$ in $2045 .^{2-4}$ The prevalence of diabetes mellitus in Indonesia increases rapidly from $5.7 \%$ in 2007 to 6.9 $\%$ in 2013 to $8.5 \%$ in $2018 . .^{5}$ Diabetes mellitus has a significant economic impact on countries, health systems, and diabetics or families through direct medical costs and job losses and reduced wages. ${ }^{5}$

Modifiable risk factors for type 2 diabetes mellitus include poor diet and nutrition, excess adiposity, low physical activity, prediabetes or impaired glucose tolerance (IGT), smoking habits, and a history of fetal exposure to high blood glucose during pregnancy. ${ }^{4}$ Recent evidence suggests an association between regular exposure to a high glycemic load diet and causing postprandial hyperglycemia. ${ }^{6-11}$ Consumption of foods with low glycemic index and high fiber has been shown to provide the same benefits as pharmacological therapy in the control of postprandial hyperglycemia in the medium term and can prevent the incidence of hypoglycemia in people with diabetes. ${ }^{11-13}$ This type of diet can improve insulin sensitivity and fat metabolism. ${ }^{14}$ This can provide a good choice for diabetics and can reduce health care costs.

Ganyong (Canna edulis) is a food source of carbohydrates with a low glycemic index (20.8) and high fiber $(8.59 \%)$. The starch content of ganyong consists of $25 \%$ amylose. ${ }^{15.16}$ The protein content of kelor (Moringa oliefera) leaves is 35\% of the dry weight. Kelor leaves contain some phytochemical compounds such as alkaloids, flavonoids, glycosides, tannins, and steroids, which have a hypoglycemic effect. ${ }^{17,18}$ Diabetics must maintain their diet, type, and calorie content in food, especially in those who use insulin secretion-enhancing drug therapy or

\footnotetext{
${ }^{1}$ Program Studi Sarjana Gizi, STIKes Panti Rapih Yogyakarta

Tantular 401, Pringwulung, Condongcatur, Depok, Sleman, D.I. Yogyakarta, Indonesia 55283

2 Ph.D. candidate in Health Sciences, Lincoln University College, Malaysia

Wisma Lincoln, No. 12-18, Jalan SS 6/12, Petaling Jaya, Selangor Darul Ehsan, Malaysia 47301

*Correspondence: email: diyansetyaji@ stikespantirapih.ac.id, HP: +62822- 374787-90
} 
insulin injection therapy. ${ }^{19}$ Ganyong-kelor snack bar is expected to have low index glycemic and can be consumed as a snack for diabetics without causing hyperglycemia.

\section{MATERIALS AND METHODS}

This research was an experimental study. Ganyong-kelor snack bar is made using ingredients such as ganyong/ canna obtained from Giwangan Market, canna flour obtained from the Center for Food and Nutrition Studies Universitas Gadjah Mada, kelor/ moringa leaves obtained from Purworejo, noncalorie sweetener, skim milk, margarine, eggs, and essence chocolate. This research has been approved and received ethical permission from Komite Etik Penelitian Kesehatan Politeknik Kesehatan (KEPK) Yogyakarta (LB.01.01/KE-01/XXXIV/731/2018). Testing of nutritional content includes analysis of protein (the Kjeldahl method), fat (the Soxhlet method), carbohydrates (the difference method), crude fiber (the gravimetric method), and amylose content (the IRRI method) carried out at the Food Technology Laboratory, Universitas Gadjah Mada.

The glycemic index test was carried out on 10 subjects who had fasted for 10 hours then ate the reference food in the form of white bread with 50 grams of carbohydrates. Every 30 minutes (for 2 hours) a $20 \mu \mathrm{L}$ blood sample was taken to measure the postprandial blood glucose level. One week later, the same procedure is carried out by providing a snack bar containing 50 grams of carbohydrates. The glycemic index was obtained by the incremental area under the blood glucose response curve (IAUC) method by comparing the area under the blood glucose response curve to a snack bar with a reference food.

\section{RESULTS}

Ten selected respondents who had signed an informed consent have normal nutritional status measured by body mass index (BMI) and fasting blood sugar 70-100 mg/dL. Respondents fasted for 10 hours and checked their blood sugar twice with an interval of 7 days. The average result of the first measurement of fasting blood sugar for all respondents was $84.90 \mathrm{mg} / \mathrm{dL}$ while the second measurement was $84.30 \mathrm{mg} / \mathrm{dL}$. The mean value of the two measurements is within the normal fasting blood glucose range $(70-100 \mathrm{mg} / \mathrm{dL})$.

After the respondents fasted and checked their fasting blood glucose levels, all respondents consumed 105 grams (50 gr carbohydrates) of bread as the reference food. Every 30 minutes after eating, the blood glucose levels were checked for each respondent. In the following week, after the respondents fasted, all respondents consumed 157 grams (50 gr carbohydrates) of the ganyong-kelor snack bar and checked their blood glucose levels every 30 minutes.

Table 1. Nutrient Content per 100g Ganyong-Kelor Snackbar

\begin{tabular}{|c|c|}
\hline Nutrient & 100 g Ganyong-Kelor Snackbar \\
\hline Energy & $230.13 \mathrm{kkal}$ \\
\hline Water & $49.79 \%$ \\
\hline Carbohydrate & $31.97 \%$ \\
\hline Amilosa & $10.04 \%$ \\
\hline Fat & $9.25 \%$ \\
\hline Protein & $4.75 \%$ \\
\hline Ash & $4.23 \%$ \\
\hline Crude fiber & $2.64 \%$ \\
\hline
\end{tabular}

The blood glucose response of each respondent after consuming the reference food and ganyongkelor snack bar is seen in Figure 1. There was an increase in blood glucose levels $(51.11 \%)$ from 84.9 $\mathrm{mg} / \mathrm{dL}$ to $128.3 \mathrm{mg} / \mathrm{dL}$ within 30 minutes after consuming bread. This blood glucose level becomes the peak of the increase in blood glucose levels. In the next 30 minutes, there was a decrease in blood glucose levels to $121.7 \mathrm{mg} / \mathrm{dL}$ or $5.14 \%$ of the peak value and continued to decrease to $24.70 \%$ at 2 hours after consuming bread.

The peak increase in blood glucose levels after snack bar consumption reached $114.7 \mathrm{mg} / \mathrm{dL}$ or
$36.06 \%$ from fasting blood glucose $(84.3 \mathrm{mg} / \mathrm{dL})$. Measurement of blood glucose levels in the next 30 minutes to 2 hours showed a decrease in blood glucose levels of $14.55 \%, 16.73 \%$, and $20.48 \%$ respectively from the highest levels. Compared to bread, consumption of the ganyong-kelor snack bar caused a slower increase in blood glucose levels and closer to normal blood glucose levels after 2 hours of snack bar consumption. The glycemic index is calculated from the increase in blood glucose with fasting glucose levels as the initial value. The glycemic index is obtained by calculating the broad curve of the increase in blood glucose levels after 
consuming bread (A) and consuming ganyong-kelor snack bar (B) in Figure 2. The B/A ratio multiplied by 100 will reveal the glycemic index of the ganyongkelor snack bar.The ganyong-kelor snack bar has a glycemic index value of 55.19. In this study, bread was used as a reference food. If this study uses glucose as a reference (glycemic index 100 and glycemic index of bread 69) and corrected bread as a reference food, it will make the glycemic index value of the ganyong-kelor snack bar to 38.08. The calculation of the glycemic load uses the convertedglycemic index value and the total carbohydrates contained in 100 grams of the food. Ganyong-kelor snack bar has a glycemic load value of 12.10.

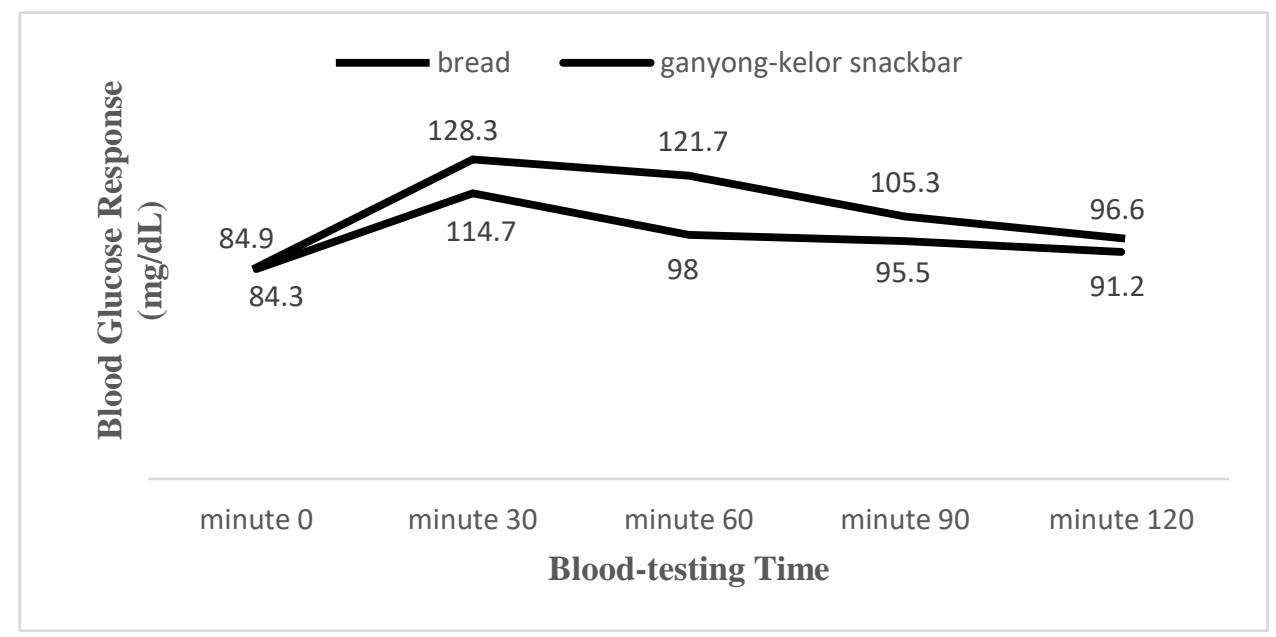

Figure 1. Blood Glucose Response After Consuming Bread and Ganyong-Kelor Snackbar

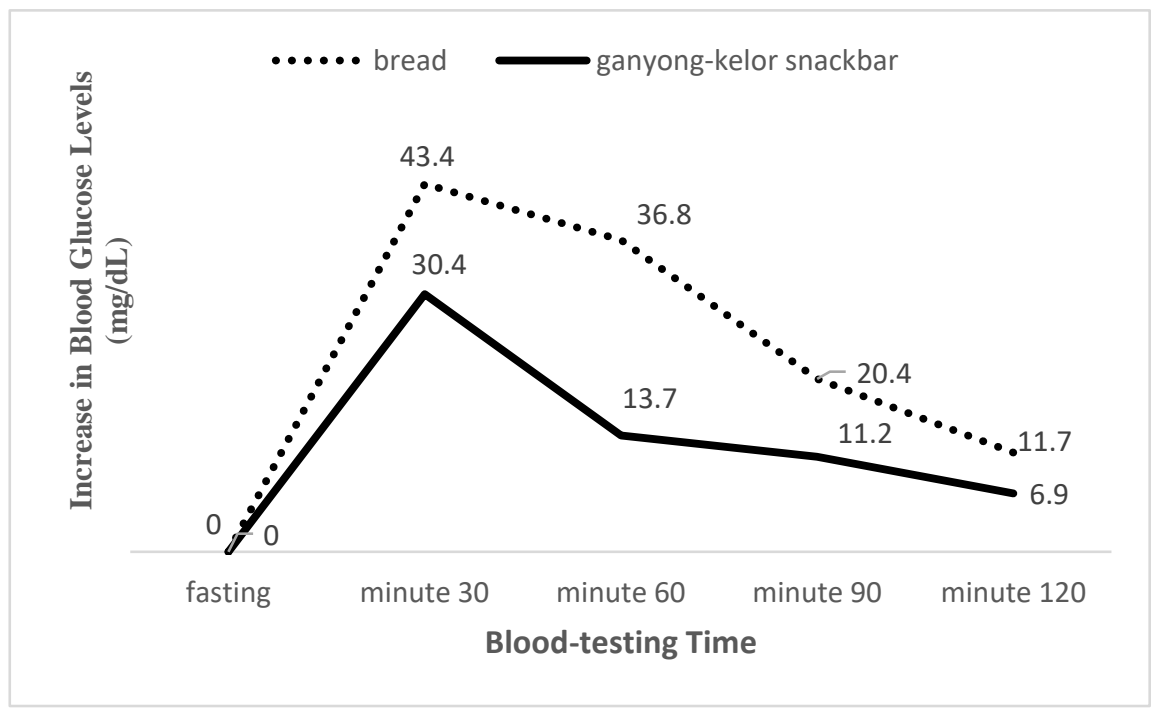

Figure 2. Increase in Blood Glucose Levels After Consuming Bread and Ganyong-Kelor Snackbar

Table 2. Glycemic Index of Ganyong-Kelor Snackbar and Bread

\begin{tabular}{lccc}
\hline \multicolumn{1}{c}{ Food } & $\begin{array}{c}\text { Glycemic Index } \\
\text { (with bread as reference) }\end{array}$ & $\begin{array}{c}\text { Glycemic Index } \\
\text { (with glucose as reference) }\end{array}$ & Glycemic Load \\
\hline Bread & 100 & 69 & 32.85 \\
ganyong-kelor snackbar & 55.19 & 38.08 & 12.10 \\
\hline
\end{tabular}

\section{DISCUSSION}

Diabetics must maintain their diet. type, and calorie content in food, especially in those who use insulin secretion-enhancing drug therapy or insulin

Copyright (C) 2021; Jurnal Gizi Indonesia (The Indonesian Journal of Nutrition), Volume 9 (2), 2021 e-ISSN: 2338-3119, p-ISSN: 1858-4942 
injection therapy. ${ }^{19} \mathrm{~A}$ snack is needed to accompany the main meal in meeting nutritional needs and to help control diabetics' blood glucose levels. Snack bars are a food product that has begun to be developed as a snack for diabetics that can help prevent hyperglycemia by using foods high in fiber and low on the glycemic index. It is recommended that diabetics have a snack that contains $10-15 \%$ of their daily energy needs and can be consumed 2-3 times a day. ${ }^{19}$

Adequate energy to do daily activities and maintain ideal body weight is met by consuming a ganyong-kelor snack bar with the appropriate portion and calorie content. Consumption of foods with excess calories can lead to obesity which is a risk factor for type 2 diabetes. ${ }^{21}$ In every 100 grams of ganyong-kelor snack bar contains 230.13 kcal. Diabetics can consume 43.45 grams of the ganyongkelor snack bar to get $100 \mathrm{kcal}$ of calorie intake. This portion contains 13.89 grams of carbohydrates, 4.01 grams of fat, and 2.06 grams of protein. Ganyongkelor snack bar has a glycemic index of 55.19. This study using bread as a reference food. If using glucose as a reference, makes the glycemic index of the ganyong-kelor snack bar to 38.08. Based on the classification of the glycemic index, after correcting the ganyong-kelor snack bar is included in a low glycemic index food (> 55).

The ingredients of the ganyong-kelor snack bar that are thought to have an impact on the low glycemic index are ganyong/ canna and kelor/ moringa leaves. In these two food ingredients, fiber content is the part that greatly affects the glycemic index. The total dietary fiber in 100 grams of canna starch ranges from 81.9 to $85.9 \%$ dry weight. The high amylose and fiber content in canna affects the low glycemic index of the ganyong-kelor snack bar. As a high-carbohydrate food, ganyong has a lower glycemic index (20.8) when compared to rice (72.8) ${ }^{15}$ Consumption of foods with a low glycemic index can improve insulin sensitivity and decrease the rate of glucose absorption which improves glycemic control in diabetics. ${ }^{11-13,22}$

Food with a low glycemic index will be digested and converted into glucose gradually and slowly resulting in a slower release of glucose into the bloodstream so that the increase in blood glucose levels will be lower and the fluctuation of the increase in blood glucose is relatively shorter. This will affect increasing insulin secretion and glucose consumption by liver cells which will result in reduced blood glucose levels. Consumption of foods with a low glycemic index can improve insulin sensitivity and reduce the rate of glucose absorption. This can improve glycemic control in people with diabetes mellitus. ${ }^{11-13,22}$ Some of the factors that influence the glycemic index are carbohydrate composition, tertiary structure, and enzymatic digestion. ${ }^{22}$ Clinical studies show that consumption of foods high in watersoluble fiber such as guar gum, pectin, $\beta$-glucans found in nuts, vegetables, fruit, and oat cereals can control insulin levels and lower postprandial blood glucose levels. ${ }^{22}$ The hypoglycemic effect of a diet high in soluble fiber can be achieved through slowing gastric emptying and enzymatic absorption, shorter intestinal transit times, and the formation of a physical barrier on carbohydrates that slows down glucose uptake. . $2,23^{2}$

The glycemic load is defined as the glycemic index of a food multiplied by the carbohydrate content in the product. The calculation of the glycemic load is intended to provide information about the effect of food consumption on increasing blood glucose levels associated with the glycemic index. The lower the carbohydrate content, the lower the glycemic load. Then the food consumed will trigger a lower increase in blood glucose levels compared to the reference food. Ganyong-kelor snack bar has a glycemic load value of 12.10 . This food is included in the category of moderate glycemic load foods (range of 11 to 19).

This study has many limitations. The material used as the standard for measuring the glycemic index is bread. The author suggests further research using glucose as a reference. However, the analysis of the results of this study can provide important evidence regarding the use of canna and moringa leaves as materials for snack bars, introducing ganyong-kelor snack bar as an alternative snack for diabetics, and can be the starting point for further research.

\section{CONCLUSIONS}

Ganyong-kelor snack bar has good nutritional content and is categorized as food with a low glycemic index. Ganyong-kelor snack bar can be consumed as a healthy snack for diabetes without causing hyperglycemia. Every 100 grams of ganyong-kelor snack bar contains calories of 230.13 kcal, 31.97 grams of carbohydrates, 9.25 grams of fat, and 4.75 grams of protein. The glycemic index of the ganyong-kelor snack bar was 38.08 (low category) with a glycemic load of 12.10 (moderate category). The hypoglycemic effect of snack bars comes from their high fiber content. The hypoglycemic effect of a diet high in fiber can be achieved through slowing gastric emptying and enzymatic absorption, shorter intestinal transit times, and the formation of a physical barrier on carbohydrates that slows down glucose uptake. Knowing the glycemic load on food will help us to choose food and determine food Copyright (C) 2021; Jurnal Gizi Indonesia (The Indonesian Journal of Nutrition), Volume 9 (2), 2021 e-ISSN: 2338-3119, p-ISSN: 1858-4942 
portions wisely so that it will limit carbohydrate intake too high which can cause an increase in blood glucose levels. This is especially important for diabetics or people who want to limit their calorie intake to control their weight.

\section{ACKNOWLEDGEMENT}

The authors have no conflict of interest to declare. This research was supported by Daftar Isian Pelaksanaan Anggaran (DIPA), Lembaga Layanan Pendidikan Tinggi (LLDIKTI) Region V 2018, contract no 1327/STIKes PR-B/VII/2018.

\section{REFERENCES}

1. World Health Organization. Definition, Diagnosis, and Classification of Diabetes Mellitus and its Complications. Part 1: Diagnosis and Classification of Diabetes Mellitus (WHO/NCD/NCS/99.2). Geneva: World Health Organization; 1999. http://apps.who.int/iris/handle/10665/66 040

2. The International Diabetes Federation. Diabetes Atlas $8^{\text {th }}$ Edition. Brussels: The International Diabetes $\quad 2017$. https://www.idf.org/e-library/epidemiologyresearch/diabetes-atlas.html

3. World Health Organization. Global report on Diabetes. Geneva: World Health Organization; 2016.

http://apps.who.int/iris/bitstream/10665/20 4871/1/9789241565257_eng.pdf

4. NCD Risk Factor Collaboration. Worldwide trends in diabetes since 1980: a pooled analysis of 751 population-based studies with 4.4 million participants. Lancet. April 2016; 387: 15131530.

http://dx.doi.org/10.1016/S01406736(16)00618-8

5. Badan Penelitian dan Pengembangan Kesehatan. Laporan Nasional Riskesdas 2018. Jakarta: Lembaga Penerbit Badan Penelitian dan Pengembangan Kesehatan; 2019.

6. Castro-Acosta ML, Stone SG, Mok JE, Mhajan RK, Fu CI, Lenihan-Geels GN, et al. Apple and blackcurrant polyphenol-rich drinks decrease postprandial glucose, insulin, and incretin response to a high-carbohydrate meal in healthy men and women. Journal of Nutritional Biochemistry. 2017; 49:53-62. DOI: http://dx.doi.org/10.1016/j.jnutbio.2017.07. 013
7. Schulze MB, Manson JE, Ludwig DS, Colditz GA, Stampfer MJ, Willett WC, et al. Sugarsweetened beverages, weight gain, and incidence of type 2 diabetes in young and middle-aged women. JAMA. 2004; 292(8): 927-34.

DOI:

http://dx.doi.org/10.1001/jama.292.8.927

8. Sluijs I, van der Schouw YT, van der AD, Spijkerman AM, Hu FB, Grobbee DE, et al. Carbohydrate quantity and quality and risk of type 2 diabetes in the European prospective investigation into cancer and nutritionNetherlands (EPIC-NL) study. Am J Clin Nutr. 2010; 92: 905-11. DOI: https://doi.org/10.3945/ajcn.2010.29620

9. de Koning L, Malik VS, Rimm EB, Willett WC, $\mathrm{Hu}$ FB. Sugar-sweetened and artificially sweetened beverage consumption and risk of type 2 diabetes in men. Am J Clin Nutr. 2011; 93(6): 1321-27. DOI: https://doi.org/10.3945/ajcn.110.007922

10. Blaak EE, Antoine JM, Benton D, Bjorck I, Bozzetto L, Brouns $F$, et al. Impact of postprandial glycemia on health and prevention of disease. Obes Rev. 2012; 13(10): 923-84. DOI: 789X.2012.01011.x

11. Riccardi G, Rivellese AA, Giacco R. Role of glycemic index and glycemic load in the healthy state, in prediabetes, and diabetes. Am J Clin Nutr. 2008; 87(1): 269S-74S. DOI: https://doi.org/10.1093/ajen/87.1.269S

12. Brand-Miller J, Hayne S, Petocz P, Colagiuri S. Low glycemic index diets in the management of diabetes: a meta-analysis of randomized controlled trials. Diabetes Care. 2003; 26(8): 2261-67.

DOI: https://doi.org/10.2337/diacare.26.8.2261

13. American Dietetic Assosiation. Nutrition recommendation and interventions for diabetes (position statement). Diabetes Care. January 2008; 31(1): S61-S78. $\quad$ DOI: https://doi.org/10.2337/dc08-S061

14. Rizkalla SW, Taghrid L, Laromiguiere M, Huet D, Boillot J, Rigoir A, et al. Improved plasma glucose control, whole-body glucose utilization, and lipid profile on a low glycemic index diet in type 2 diabetic men. Diabetes Care. 2004; 27(8): 1866-72.

DOI: https://doi.org/10.2337/diacare.27.8.1866

15. Lukitaningsih E, Rumiyati, Ika Puspitasari. Kajian glisemik indeks dan makronutrien dari umbi-umbian dalam upaya pencarian sumber pangan fungsional. Pharmacon. 2012; 13(1): 18- 
23.

https://publikasiilmiah.ums.ac.id/bitstream/han

dle/11617/3377/2012-13-1-

18.pdf? sequence $=1 \&$ is Allowed $=\mathrm{y}$

16. Carolina A, Ilmi FN. Production of Indonesian canna edulis type iv resistant starch through acetylation modification. International Food Research Journal. 2016; 23(2): 491-97. http://www.ifrj.upm.edu.my/23\%20(02)\%2020 $16 /(6) . p d f$

17. Tshingani K, Donnen P, Mukumbi H, Duez P, Dramaix-Wilmet M. Impact of Moringa oleifera lam. leaf powder supplementation versus nutritional counseling on the body mass index and immune response of HIV patients on antiretroviral therapy: a single-blind randomized control trial. BMC Complementary and Alternative Medicine. 2017; 17:420-33. DOI: https://doi.org/10.1186/s12906-017-1920-z

18. Jaiswal D, Rai PK, Mehta S, Chatterji S, Shukla S, Rai DK, et al. Role of Moringa oleifera in regulation of diabetes-induced oxidative stress. Asian Pacific Journal of Tropical Medicine. 2013; 6(6): 426-32. DOI: https://doi.org/10.1016/S1995-7645(13)600681

19. Perkumpulan Endokrinologi Indonesia. Konsensus pengelolaan dan pencegahan diabetes melitus tipe 2 di Indonesia 2015. Jakarta: PB. Perkeni; 2015. https://pbperkeni.or.id/wpcontent/uploads/2019/01/4.-KonsensusPengelolaan-dan-Pencegahan-Diabetes-melitustipe-2-di-Indonesia-PERKENI-2015.pdf

20. Mortensen A. Sweeteners permitted in the European Union: safety aspects. Scandinavian Journal of Food and Nutrition. 2006; 50(3): 10416.

DOI: https://doi.org/10.1080/17482970600982719

21. Franz MJ. Medical nutrition therapy for diabetes mellitus and hypoglycemia of nondiabetic origin. In: Mahan LK, Escottt-Stump S. Krause's food, and the nutrition care process. $13^{\text {th }}$ edition. Philadelphia: Elsevier; 2012. 675710.

22. Frost G. Carbohydrate: Glucose tolerance and the glycemic (glycaemic) index. In: Caballero B. Encyclopedia of food sciences and nutrition. New York: Academic Press; 2003. 2917-22.

23. Gallagher ML. Intake: The nutrient and their metabolism. In: Mahan LK, Escottt-Stump S. Krause's food, and the nutrition care process. $13^{\text {th }}$ edition. Philadelphia: Elsevier; 2012. 32-41. 